\title{
Implementation of the principles of rational incentive system in modern conditions on an example of sectoral enterprises
}

\author{
Natalia Zotkina ${ }^{1}$, Anna Kopytova ${ }^{1, *}$, Marina Zenkina ${ }^{1}$, and Olga Zhigunova ${ }^{1}$ \\ ${ }^{1}$ Industrial university of Tyumen, Volodarskogo str. 38, Tyumen, 625001, Russia
}

\begin{abstract}
This article is focused on studying of the problem of workers incentives on the example of one of Russian regions. The authors studied the characteristics of personnel matters in the Tyumen region enterprises. Workers incentive is the most important tool which influences the staff motivation and the mood of an individual worker. The rational incentive system provides a number of principles, implementation of which is relevant in formation of the system of values which are the foundation of the employee motivation system. In order to study the implementation of the principles of rational incentive system in modern conditions the authors conducted a survey. The managers of the industrial enterprises operating in the market of the city of Tyumen became the respondents of the survey. The respondents filled in the questionnaire developed by the authors. The processing of the received data revealed a number of interesting points, which are disclosed in this article.
\end{abstract}

\section{Introduction}

Managers of a number of economic entities were surveyed to identify the features of existing businesses in the markets of the Tyumen. The study was intended to identify the possibility of implementation of the proposed RIS principles in modern conditions by organizations of the Tyumen region, as well as to assess the actual situation of their using by organizations in their work. The study was conducted in period from 16 February to 5 April 2015. The survey was conducted at the same time. The sample size was according to the plan 550 respondents ( 70 companies), in fact amounted to 492 respondents (64 companies). The sample included the management staff.

Respondents were asked to assess whether the functioning on their enterprise incentive system established eleven principles of the system rationality on the scale from 1 to 5 . The mark 1 means that the system absolutely does not meet this principle, and the mark 5 means that principle clearly works.

Respondents were experts-representatives of a particular sector. Companies were classified to certain sectors in accordance with their open economic activities, as outlined in the current extract from the united state register of legal entities / individual entrepreneurs.

* Corresponding author: a.copytowa@yandex.ru 
The views of the expert group for each sector were reduced to a complex indicator. The range of possible values of complex parameters ranged from 0 to 1 . A value of 0 indicates that, according to respondents, indicated principle of operation of the current incentive system doesn't function at all, and a value of 1 indicates that the current incentive system in the enterprise meets the designated principle.

\section{Methods}

Proposed Conformity assessment of the current RIS to the established principles is carried out by an expert. Expert Group is formed on the base of well-known rules [1, 4, 6, 8, 9, etc.]. Expert review provides

1. The formation of an expert group. The group is formed of employees of enterprises of different sectors. Respondents belong to the governing stuff;

2. Experts make themselves familiar with the assessment rules and the proposed questionnaire. Each one fills in the questionnaire individually, without the ability to discuss collectively issues raised therein;

3. Processing of questionnaires, analysis of expert opinions, expert consistency coefficients calculation, summing up;

4. Introduction of the expert group to the results of discussion.

A key element of the questionnaire offered to the experts, is presented in Table 1.

Table 1. Expert opinion on the implementation of these principles in the functioning of the existing incentive systems in the enterprise

\begin{tabular}{|c|c|c|c|c|c|c|}
\hline \multirow{2}{*}{ № } & \multirow{2}{*}{ Principless } & \multicolumn{5}{|c|}{$\operatorname{mark} *$} \\
\hline & & 1 & 2 & 3 & 4 & 5 \\
\hline 1 & logic & & & & & \\
\hline 2 & Scientific character & & & & & \\
\hline 3 & availability (clarity, intelligibility) & & & & & \\
\hline 4 & social importance & & & & & \\
\hline 5 & economic advantages for the worker & & & & & \\
\hline 6 & economic advantage for the employer & & & & & \\
\hline 7 & accounting of remuneration in the foreign market & & & & & \\
\hline 8 & compliance with current legislation & & & & & \\
\hline 9 & $\begin{array}{l}\text { fairness in the evaluation of the labor costs of } \\
\text { employees and the contribution of this work to the } \\
\text { final results of the enterprise }\end{array}$ & & & & & \\
\hline 10 & $\begin{array}{l}\text { account of features of the company and the working } \\
\text { process of different groups of workers }\end{array}$ & & & & & \\
\hline 11 & $\begin{array}{l}\text { creating conditions for adequate wages for all } \\
\text { groups of workers }\end{array}$ & & & & & \\
\hline \multicolumn{7}{|c|}{$\begin{array}{l}\text { * Do you think that the current incentives system in the enterprise meets these principles? } \\
1 \text { - absolutely not meets; }\end{array}$} \\
\hline
\end{tabular}

Processing of questionnaires occurred as follows. Each invoiced by an expert assessment tends to its maximum value. Placing higher (five) points for each principle says that the current incentive system meets the proposed principles.

For interpretation of the values of complex parameters of experts it is recommended to use the desirability scale of Harrington (Table 2). 
Table 2. Level practical implementation of the RIS principles evaluation scale

\begin{tabular}{|c|c|c|}
\hline $\begin{array}{l}\text { The numerical } \\
\text { value of the } \\
\text { complex index }\end{array}$ & $\begin{array}{c}\text { Graduations of } \\
\text { compliance with } \\
\text { the principles of } \\
\text { the RIS }\end{array}$ & Interpretation of values \\
\hline $0-0.2$ & very low & $\begin{array}{l}\text { It is necessary to reconsider the principles of incentive } \\
\text { systems because the organization can not carry out } \\
\text { current principles in practice, }\end{array}$ \\
\hline $0.2-0.37$ & low & $\begin{array}{l}\text { Particular indicators of experts should be carefully } \\
\text { considered - some principles of incentive systems are not } \\
\text { rational for the organization, they should be excluded }\end{array}$ \\
\hline $0.37-0.63$ & average & $\begin{array}{l}\text { It is recommended either to partially revise the principles } \\
\text { of the RIS, or to strengthen control of their execution }\end{array}$ \\
\hline $0.63-0.8$ & high & $\begin{array}{l}\text { most of the set out principles are satisfied, in general, } \\
\text { system is rational for the organization }\end{array}$ \\
\hline $0.8-1$ & Very high & $\begin{array}{l}\text { indicated principles are met, a system is rational for the } \\
\text { organization }\end{array}$ \\
\hline
\end{tabular}

Assessment of compliance with the principles of RIS allows:

1. Determine which RIS principles are the most difficult to implement (hereinafter analysis of the causes may be carried out);

2. Identify the consistency of expert opinion. Experts are sources of information about the comprehensive motivational mood of enterprise employees;

3. Develop recommendations for improving the current incentive system.

\section{Assessment and Results}

For each element of the proposed RIS The results are given in Table 3.

The coefficients of compliance are submitted by the following principles (numbering according to the Table 3):

1) The principle of logic;

2) The principle of scientific character;

3) The principle of availability (clarity, intelligibility) for understanding by the subjects of social and labor relations;

4) The principle of social importance;

5) The principle of economic advantage for the employee (the employee is satisfied with this level of remuneration);

6) The principle of economic profitability for the employer (valid for the employer level of staff costs);

7) The principle of accounting the level of remuneration in the foreign market;

8) The principle of compliance with applicable legislation;

9) The principle of fairness in the assessment of the labor costs of employees and the contribution of this work to the final results of the enterprise;

10) The principle of taking into account specificity of the enterprise and work processes of different groups of workers;

11) The principle of creating the conditions for adequate wages for all groups of workers. [9] 
Table 3. Summary of indicators degree of the RIS principles implementation at the enterprises of various sectors in the Tyumen region

\begin{tabular}{|c|c|c|c|c|c|c|c|c|c|c|c|c|}
\hline \multirow{2}{*}{ № } & \multirow{2}{*}{$\begin{array}{l}\text { Sector in accordance } \\
\text { with the exposed } \\
\text { economic activities }\end{array}$} & \multicolumn{11}{|c|}{ The coefficients for the principles of the system RIS } \\
\hline & & 1 & 2 & 3 & 4 & 5 & 6 & 7 & 8 & 9 & 10 & 11 \\
\hline 1 & Agriculture & 0.5 & 0.4 & 0.6 & 0.7 & 0.6 & 0.6 & 0.6 & 0.8 & 0.6 & 0.7 & 0.6 \\
\hline 2 & Mining and quarrying & 0.6 & 0.5 & 0.9 & 0.9 & 0.9 & 0.9 & 0.9 & 1 & 0.8 & 0.9 & 0.9 \\
\hline 3 & $\begin{array}{l}\text { manufacturing } \\
\text { activity }\end{array}$ & 0.6 & 0.4 & 0.8 & 0.8 & 0.8 & 0.8 & 0.9 & 1 & 0.8 & 0.8 & 0.9 \\
\hline 4 & Construction & 0.7 & 0.4 & 0.7 & 0.8 & 0.8 & 0.8 & 0.8 & 0.9 & 0.7 & 0.8 & 0.7 \\
\hline 5 & Trading & 0.8 & 0.3 & 0.9 & 0.6 & 0.8 & 0.8 & 0.8 & 0.8 & 0.7 & 0.8 & 0.8 \\
\hline 6 & Transportation & 0.6 & 0.6 & 0.7 & 0.6 & 0.7 & 0.8 & 0.7 & 0.8 & 0.6 & 0.6 & 0.7 \\
\hline 7 & $\begin{array}{l}\text { Public catering } \\
\text { companies }\end{array}$ & 0.6 & 0.6 & 0.8 & 0.6 & 0.6 & 0.9 & 0.7 & 0.8 & 0.6 & 0.6 & 0.8 \\
\hline 8 & $\begin{array}{l}\text { Activities in the field } \\
\text { of information and } \\
\text { communication }\end{array}$ & 0.7 & 0.6 & 0.7 & 0.7 & 0.6 & 0.8 & 0.7 & 0.9 & 0.7 & 0.6 & 0.8 \\
\hline 9 & Financial activities & 0.8 & 0.6 & 0.9 & 0.6 & 0.7 & 0.8 & 0.9 & 0.7 & 0.9 & 0.8 & 0.9 \\
\hline 10 & $\begin{array}{l}\text { Professional, } \\
\text { scientific and } \\
\text { technical activities }\end{array}$ & 0.7 & 0.6 & 0.6 & 0.5 & 0.7 & 0.8 & 0.7 & 0.8 & 0.7 & 0.6 & 0.8 \\
\hline 11 & $\begin{array}{l}\text { Administrative } \\
\text { activities and related } \\
\text { additional services }\end{array}$ & 0.6 & 0.4 & 0.8 & 0.6 & 0.6 & 0.6 & 0.6 & 0.7 & 0.7 & 0.7 & 0.8 \\
\hline 12 & Education & 0.7 & 0.8 & 0.6 & 0.7 & 0.6 & 0.7 & 0.7 & 0.9 & 0.6 & 0.6 & 0.6 \\
\hline 13 & $\begin{array}{l}\text { Activities in the field } \\
\text { of culture, sport, } \\
\text { leisure and } \\
\text { entertainment }\end{array}$ & 0.6 & 0.4 & 0.2 & 0.2 & 0.6 & 0.8 & 0,8 & 0.6 & 0.6 & 0,6 & 0.6 \\
\hline
\end{tabular}

According to the survey, the sectors "Mining" and "Manufacturing" have the highest rates for almost all the eleven principles. This suggests that the incentive systems existing in these enterprises are effective, and making changes in there should be extremely cautious. The low value is observed according to the principle of scientific character. This suggests that there is a need to study the data of the labor process, identifying features and characteristics of these enterprises.

For the sector "Agriculture" the indicators are low or average values on almost every principle, except for the principles of social importance, compliance with current legislation and taking into account specificity of the enterprise and work processes of different groups of workers. This suggests that there are problems in the sector with workers incentives. It is needed the careful study of the features inherent in agriculture to build an effective labor incentives system that can have a positive impact on the employees of this sector, making this area attractive for job seekers. Agriculture is an important sector of the economy, focused on providing the population with food products, so there is a need to create the most favorable conditions for the labor force of this sector.

Index of scientific principle was very low in the opinion of management staff of organizations surveyed in the sectors "Construction" and "Trade". This indicates that the problem of workers incentives is studied scientifically not well enough. The same indicator in the sector "Transport" has an average value. Most of the principles of the sector "Transport" have estimated average or high values. Sector "Trade" has a very high value of the index for the third principle, this indicates that the current incentive system is the most clear for personnel (employees are well aware what affects the value of their remuneration). 
RIS principles are valued positive in the sector "Construction". According to the respondents, all of these principles are implemented in the operation of incentive systems.

Respondents - representatives of the industry "Public catering companies" noted the average values for a large number of proposed principles - logical, scientific, social importance, economic profitability for employee, equity when assessing labor costs, taking into account the specifics of the enterprise and work processes of different groups of workers. The index on the sixth principle is very high. It says that the employees feel that the employer benefits from their work more than they do (the rate of principle of economic advantage for the employee is low, the value is in the neutral zone). Retailing representatives believe that the distribution of remuneration is not the fairest way. This is an alarming signal - if employee stress is not removed, the employees will do it on their own (in case of the sphere of trade, they can withhold revenues, reduce the quality of service, etc.).

The survey of the sector "Activities in the field of information and communication" has shown that in the middle zone are metric values on the scientific principles, cost-effective for the employee, and consideration of the specific activity of the enterprise and work processes of different groups of workers.

The sector "Financial activity" is characterized by very high values of indicators on the principle of availability (clarity, intelligibility); compliance with the wage level in the foreign market; fairness in the evaluation of the labor costs of employees and the contribution of this work to the final results of the enterprise; the principle of the creation of conditions for adequate wages for all groups of workers.

In the middle zone on the scale of Harrington is the value of the indicator on scientific principles and social significance. This suggests that these principles are not sufficiently implemented in the existing conditions, according to respondents surveyed in the sector "Financial activities".

In the low zone on the principles of the RIS graduation are indexes of the companies operating in the sector "Activities in the field of culture, sport, leisure and entertainment" for the scientific principle,. availability (clarity, intelligibility) and social importance. In general, the indicators for the sector "Activities in the field of culture, sport, leisure and entertainment" are in the middle zone. In the high zone are indicators on the principle of economic profitability for the employer (valid for the employer level staff costs); accounting of wage level in the foreign market; the principle of the creation of conditions for adequate wages for all groups of workers.

For the sector "Professional, scientific and technical activities" values of the indicators that reflect the degree of practical implementation of the principles of the RIS are mostly in the middle zone. In very high zone are the values of the coefficients on the principles of: economic profitability for the employer (valid for the employer level staff costs); compliance with applicable legislation; creating conditions for adequate wages for all groups of workers.

In the sector "administrative activities and related additional services" the principle of scientific character is not satisfied in the opinion of the respondents (in the lower zone on the respect for the RIS principles graduation). In the very high zone are values of the indicators on two principles - accessibility (clarity, intelligibility) and creating conditions for adequate wages for all groups of workers. Other values are in the middle zone.

\section{Conclusions}

Managers of a number of economic entities were surveyed to identify the features and opportunities offered by the principles of the RIS formation in the existing enterprises of the Tyumen region in various fields. The purpose of the study was to identify the possibility 
of the proposed RIS principles implementation in modern conditions, as well as to evaluate the actual situation of the use by enterprises in their activities.

The study led to the conclusion that in most sectoral enterprises scientific principle is almost never used - respondents gave it the lowest mark of all the proposed principles of the RIS formation. This indicates that the studying of problem of workers incentives from a scientific point of view is not sufficient and needs attention. The values of integrated indicators reflect that in the middle zone on the Harrington's desirability scale are two sectors: "administrative activities and related additional services "and" Activities in the field of culture, sport, leisure and entertainment organizations. " The other sectors are in the high zone, and two sectors "Mining" and "Manufacturing" are in a very high area. This suggests that the principles of the RIS can be actually accomplished nowadays.

\section{References}

1. M. Bonenberger, M. Aikins, P. Akweongo, K. Wyss, Human Resources for Health, 12, 43 (2014)

2. R. Urheim, K. Rypdal, O. Melkevik, H.A. Hoff, A. Mykletun, T. Palmstierna, Criminal Behaviour and Mental Health, 24, 141 (2014)

3. A. Jakubowska, M.J. Woolga, P.A. Haselton, A. Jones, Eating Disorders, 21, 16 (2013)

4. A. Battistelli, M. Galletta, I. Portoghese, C. Vandenberghe, Journal of Psychology: Interdisciplinary and Applied, 147, 17 (2013)

5. K.A. Saka, I. Haruna, Mediterranean Journal of Social Sciences, 4, 9 (2013)

6. R.N. Osakwe, International Education Studies, 7, 43 (2014)

7. R.A. Edwards, J. Kirwin, M. Gonyeau, S.J. Matthews, J. Lancaster, M. DiVall, Am. J. of Pharmaceutical Education, 78, 103 (2014)

8. V.G. Nemirovskiy, V.S. Polovinko, Sotsiologicheskie Issledovaniya, 1, 27 (2015)

9. A.Kopytova, Procedia Engineering ,165, 1132 (2016)

10. M.V. Simonova, L.V. Sankova, F.I. Mirzabalaeva, D.Y. Shchipanova, V.E. Dorozhkin, Int. J. of Environmental and Science Education, 11, 7608 (2016)

11. M.V. Sturikova, N.V. Albrekht, I.M. Kondyurina, S.S. Rozhneva, L.V. Sankova, E.S. Morozova, Int. J. of Environmental and Science Education, 11, 7826 (2016)

12. C. Saver, OR manager, 32, 18 (2016)

13. M. Kukla, A.B. McGuire, M.P. Salyers, Psychiatric Services, 67, 412 (2016)

14. M.E. Kreye, Production Planning and Control, 27, 1249 (2016)

15. R. Engbers, C.R.M.G. Fluit, S. Bolhuis, R. Sluiter, P.M.J. Stuyt, R.F.J.M. Laan, Advances in Health Sciences Education, 20, 969 (2014)

16. Z. Yuan, Y. Li, L.E. Tetrick, Applied Ergonomics, 51, 163 (2015)

17. E. Bartle, J. Thistlethwaite, BMC Medical Education, 14, 110 (2014)

18. T. Keskitalo, H. Ruokamo, D. Gaba, Medical Teacher, 36, 230 (2014) 